\title{
Dayua Dukung Tanah Pasir Dengan Perkuatan Geotekstil Tipe UW 150 Terhadap Variasi Lebar Fondasi dan Perkuatan
}

\author{
Martini $^{\mathbf{a}^{*}}$, V.I. Cristina ${ }^{\mathrm{a}}$ \\ a Jurusan Teknik Sipil, Fakultas Teknik Universitas Tadulako, Palu, Indonesia. \\ ${ }^{*}$ Corresponding author's e-mail: martini_geotech@yahoo.com
}

Received: 30 May 2021; revised: 19 July 2021; accepted: 24 July 2021

\begin{abstract}
Sand are soils that have low bearing capacity and are more affected by density. Therefore it is necessary to improve sand soil to increase the bearing capacity of the soil. One method of soil mechanical improvement is by inserting a sheet of reinforcement (geotextile) on the sand. The purpose of this research is to study the relationship of width of foundation (B) and width of reinforcement $(\mathrm{Br})$ in increasing the support capacity of sandy soil and to know soil bearing capacity of sand at condition without and with reinforcement.The purpose of this research to know the modeling on sand in a test tub madeby steel plate with size $80 \mathrm{~cm} \times 80 \mathrm{~cm}$ with a shallow foundation model measuring $8 \mathrm{~cm} \times 8 \mathrm{~cm}, 10 \mathrm{~cm} \times 10 \mathrm{~cm}$ and $12 \mathrm{~cm} \times 12 \mathrm{~cm}$. Loading is given by using a hydraulic jack. The soil is formed with a $50 \%$ relative density with the width of reinforcement $(\mathrm{Br})$ inserted were $4 \mathrm{~B}, 5 \mathrm{~B}$ and $6 \mathrm{~B}$ with the depth $(\mathrm{u}) 0.5 \mathrm{~B}$, spacing $(\mathrm{z})$ $0.25 \mathrm{~B}$ and a 3 -sheet reinforecment $(\mathrm{N})$ ), where $\mathrm{B}$ is the width Foundation. Furthermore, it is determined the bearing capacity of the limit and the ratio of its bearing capacity (BCR). The result shows that giving the geotextile sheet on sand soil can increase the bearing capacity against the condition without reinforcement. Bearing capacity increases as the width of the foundation (B) is wider and the width of reinforcement $(\mathrm{Br})$ or geotextile is wider. Based on the Tangent Intersection Method theory, the largest bearing capacity obtained at the width of the foundation (B) $12 \mathrm{~cm} \times 12 \mathrm{~cm}$ and the reinforcing width $(\mathrm{Br}) 6 \mathrm{~B}$ is $153 \mathrm{kN} / \mathrm{m}^{2}$ with 2.06 of the bearing capacity ratio. For the vesic theory, the largest bearing capacity obtained at the width of the foundation (B) $12 \mathrm{~cm} \mathrm{x} 12 \mathrm{~cm} 274 \mathrm{kN} / \mathrm{m}^{2}$ for the width of the $6 \mathrm{~B}$ reinforcement with 3.32 of the bearing capacity ratio (BCR).
\end{abstract}

Keywords: foundation, geotextile, bearing capacity, sand, BCR.

\begin{abstract}
Abstrak: Tanah pasir adalah tanah yang memiliki daya dukung yang rendah serta lebih dipengaruhi oleh kepadatan tanah. Oleh sebab itu perlu dilakukan perbaikan tanah pasir untuk dapat meningkatkan daya dukung tanah pasir. Salah satu metode perbaikan tanah secara mekanis yaitu dengan menyisipkan lembar perkuatan (geotekstil) pada tanah pasir tersebut. Tujuan dari penelitian ini adalah mengkaji hubungan lebar fondasi (B) dan lebar perkuatan (Br) dalam meningkatkan daya dukung tanah berpasir serta mengetahui daya dukung tanah pasir pada kondisi tanpa dan dengan perkuatan. Penelitian ini bertujuan untuk mengetahui pemodelan pada tanah pasir dalam bak uji yang terbuat dari plat baja berukuran $80 \mathrm{~cm}$ x $80 \mathrm{~cm}$ dengan model pondasi dangkal berukuran $8 \mathrm{~cm} \times 8 \mathrm{~cm}, 10 \mathrm{~cm} \times 10 \mathrm{~cm} \mathrm{dan} 12 \mathrm{~cm} \times 12$ $\mathrm{cm}$. Pembebanan diberikan dengan menggunakan alat hydraulic jack. Tanah dibentuk dengan kerapatan relatif 50\% dan lebar perkuatan (Br) yang disisipkan berukuran 4B, 5B dan 6B dengan kedalaman (u) 0,5B, spasi(z) 0,25B dan jumlah perkuatan(N) 3 lembar, dimana B adalah lebar pondasi. Selanjutnya, ditentukan daya dukung batas dan rasio daya dukungnya (BCR). Hasil penelitian memperlihatkan bahwa pemberian lembar geotekstil dapat meningkatkan daya dukung pada tanah pasir terhadap kondisi tanpa perkuatan. Daya dukung semakin meningkat bila lebar pondasi (B) semakin besar serta lebar perkuatan (Br) atau geotekstil semakin besar. Daya dukung terbesar berdasarkan teori Tangent Intersection Method diperoleh pada lebar pondasi (B) $12 \mathrm{~cm}$ x $12 \mathrm{~cm}$ dan lebar perkuatan (Br) $6 \mathrm{~B}$ sebesar $153 \mathrm{kN} / \mathrm{m}^{2}$ dengan rasio daya dukung sebesar 2,06. Untuk teori vesic daya dukung terbesar diperoleh pada lebar pondasi (B) $12 \mathrm{~cm} \times 12$ $\mathrm{cm} 274 \mathrm{kN} / \mathrm{m}^{2}$ untuk lebar perkuatan 6B dengan rasio daya dukung (BCR) sebesar 3,32.
\end{abstract}

Kata kunci: pondasi, geotextile, daya dukung, pasir, BCR.

\section{Pendahuluan}

Daya dukung tanah berpasir besarannya tergantung pada tingkat kepadatannya. Ukuran kepadatan tanah berpasir diistilahkan dengan kerapatan relative, Dr. Kisaran nilai Dr $>0 \%$ dan paling maksimum sebesar $100 \%$. Daya dukung tanah berpasir pada Dr $<50 \%$ cenderung rendah, sehingga perlu dilakukan perbaikan tanah untuk menaikkan daya dukungnya. Usaha perbaikan tanah dapat dilakukan secara kimiawi, mekanis dan perkuatan. Metode perbaikan tanah dengan perkuatan adalah dengan cara menyisipkan lembaran-lembaran geotekstil atau batang-batang baja ke dalam tanah [1-5]. Metode perkuatan tanah bertujuan untuk memperbaiki kualitas tanah tersebut, khususnya terhadap daya dukung tananya yang berkaitan erat dengan kekuatan geser tanah [6-8]. Pada penelitian ini pemodelan daya dukung tanah dilakukan skala laboraorium menggunakan kotak baja berukuran $80 \times 80 \times 80 \mathrm{~cm} 3$. Kepadatan tanah dibuat pada Dr 50\% dan menggunakan 3 lembar geotekstil serta 3 ukuran ponds bujursangkar. Lebar perkuatan akan divariasikan 4B, 5B dan 6B., dengan B adalah lebar pondasi.

\subsection{Konsep Tanah Bertulang}

Sistem penulangan tanah untuk struktur yang terbentuk oleh tanah timbunan baru dapat dibedakan menurut jenis tulangan yang dipakai untuk memperkuat tanah. Jenis-jenis tulangan yang digunakan antara lain: 
1). Tulangan Lajur

Pada sistem tulangan lajur (strip reinforcement), suatu material komposit yang terbentuk diperoleh dengan menempatkan lajur-lajur tulangan metal pada posisi horizontal diantara lapisan-lapisan tanah urug yang dipadatkan (Gambar 1).

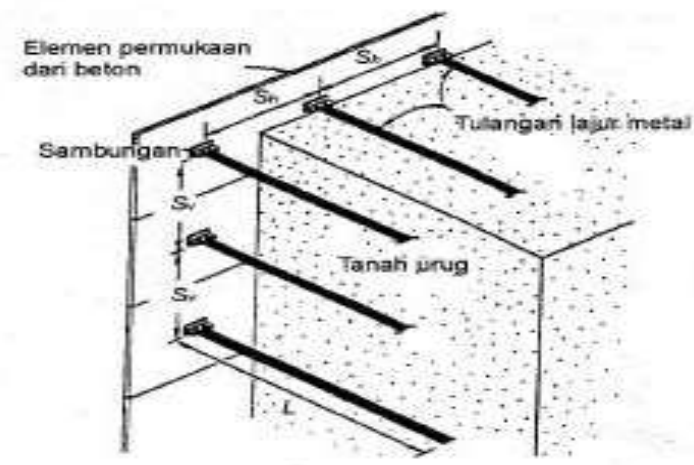

Gambar 1. Dinding tanah bertulang dengan lajur.

2). Tulangan Grid

Sistem tulangan grid (grid reinforcement) terdiri dari rakit batang-batang metal atau polimer yang terdiri atas lembaran-lembaran yang berlubang-lubang dalam bentuk empat persegi panjang yang diletakkan dalam posisi horizontal. Skema tulangan grid dilihat pada Gambar 2.
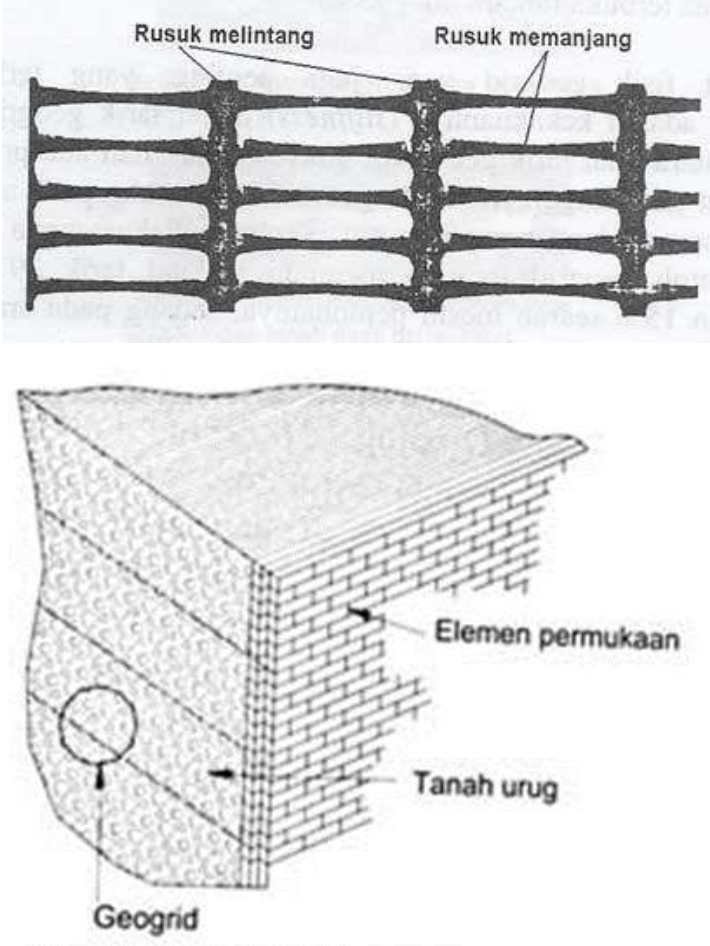

Gambar 2. Dinding tanah bertulang dengan grid

3). Tulangan Lembaran

Gambar 3 adalah perkuatan dengan tulangan lembaran. Tulangan-tulangan yang berbentuk lembaran umumnya berupa berupa bahan geotekstil. Tulangan yang terdiri dari lembaran-lembaran geotekstil diletakkan diantara lapisan-lapisan tanah urug yang keduanya membentuk material komposit. Pada sistem ini, transfer tegangan antara tanah dan lembaran- lembaran geotekstil terutama dari gesekan antara kedua material tersebut.

Umumnya, geotekstil yang digunakan untuk penulangan tanah dibuat dari polyester atau serat-serat polypropylene. Bila ditinjau dari serat-serat pembentuk bahannya, geotekstil terdiri dari 2 tipe, yaitu anyam (woven) dan nir-anyam (non anyam).

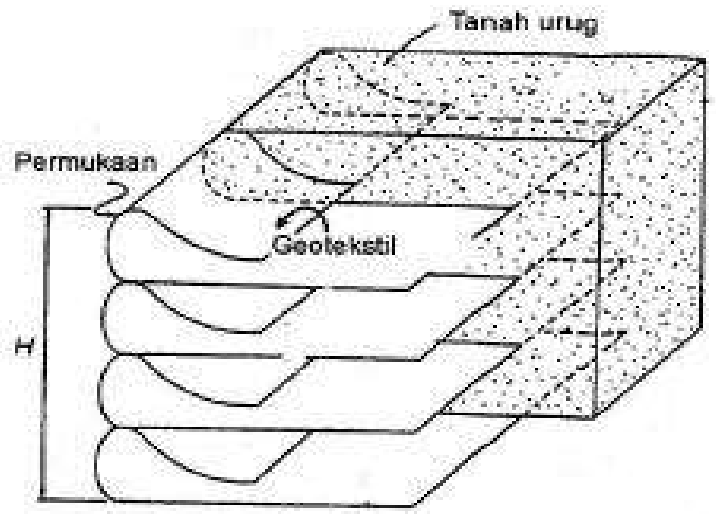

Gambar 3. Dinding tanah bertulang dengan lembaran

\subsection{Kuat Geser Tanah Bertulang}

Mekanisme kenaikan kuat geser tanah yang diperkuat dengan tulangan (baja maupun plastik) telah diterangkan menurut beberapa cara. Hardiyatmo (2014) [9], menjelaskan bahwa kuat tarik tulangan dan transfer tegangan dalam tanah ke tulangan-tulangan menghasilkan kohesi tampak (apparent cohesion) pada Gambar 4. Sedangkan dalam Basset dan Last (1978) menganggap bahwa tulangan memberikan tahanan anisotropis terhadap deformasi tanah searah dengan tulangan [10]. Hal ini mengakibatkan tegangan dan regangan utama berotasi .

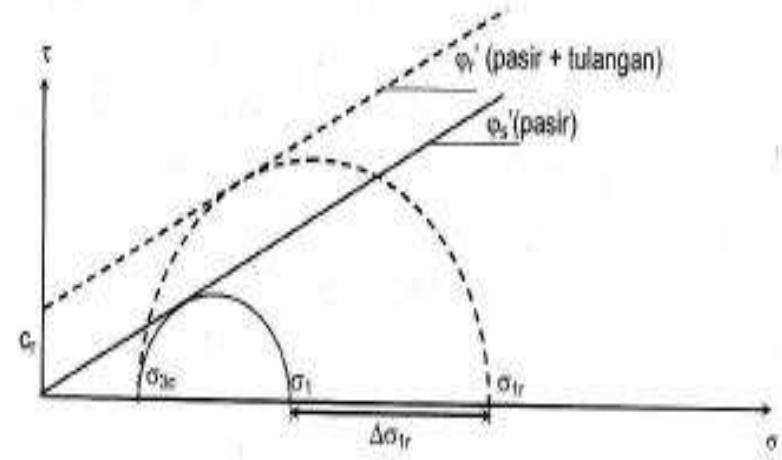

Gambar 4. Konsep kohesi nampak (apparent cohesion)

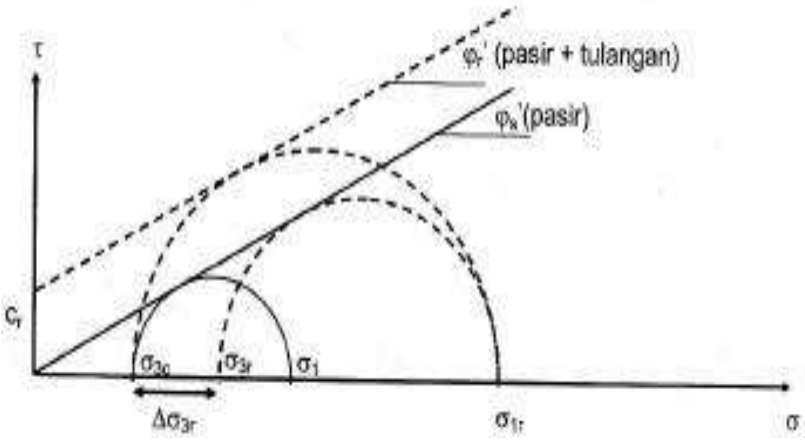

Gambar 5. Konsep kenaikan tegangan kekang 
Dengan tegangan kekang (confining stress) kecil, sistem akan runtuh sebagai akibat penggelinciran (sliding) diantara tanah dan tulangan. Sebaliknya, dengan tegangan kekang besar sistem tersebut akan runtuh sebagai akibat patahnya tulangan. Kelakuan ini dibuktikan oleh Schlosser dan Long (1972) dari hasil uji triaksial kompresi pada contoh tanah yang ditulangi dengan lembaran-lembaran aluminium [9].

Dalam daerah dimana keruntuhan disebabkan oleh putusnya tulangan, kekuatan sistem bertambah oleh pengaruh konsep kohesi tampak (apparent cohesion). Hal ini diperlihatkan dalam lingkaran Mohr pada Gambar 5. dalam gambar tersebut, cr adalah kohesi tampak dan $\sigma 1 \mathrm{r}$ adalah tegangan utama mayor pada saat kegagalan akibat pengaruh tulangan. Sudut gesek dalam pasir bertulang diambil sama dengan sudut gesek dalam tanah tak bertulang, hal ini sesuai anggapan yang diperlihatkan Gambar 6.

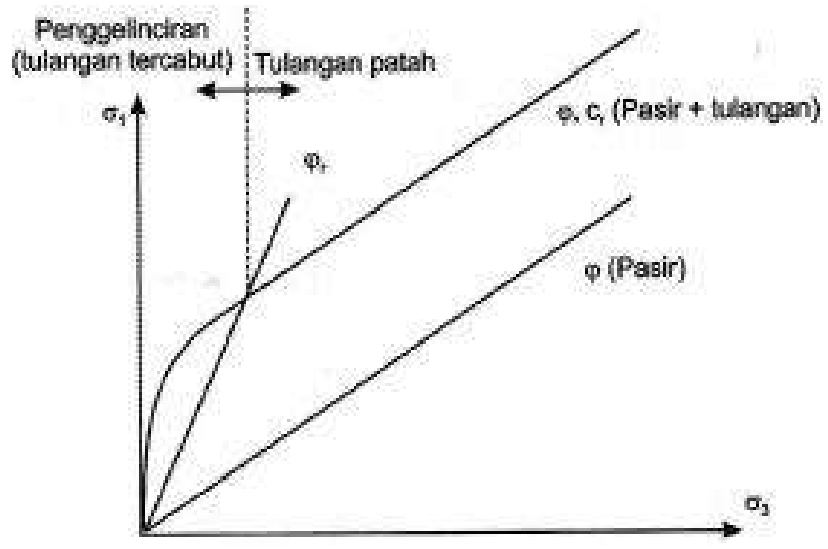

Gambar 6. Selubung kegagalan untuk pasir tak bertulang dan bertulang

\subsection{Daya Dukung Tanah Dengan Perkuatan}

Menurut Mitchell dan Villet (1987 dalam suatu perkuatan tanah kombinasi antara material tanah dan perkuatan harus sedemikian rupa sehingga interaksi antara keduanya menghasilkan material komposit yang perilakunya jauh lebih baik [11-13]. Tanah yang umumnya memiliki kekuatan tekan yang baik dan kemampuan tarik yang sangat lemah dapat diperbaiki perilakunya dengan menambahkan perkuatan yang memiliki kekuatan tarik. Kerjasama kedua material ini dapat menghasilkan material koheren dan memperbaiki perilaku teknis tanah asli. Perbaikan perilaku teknis tanah asli ini terjadi karena adanya transfer beban antara perkuatan dan tanah.

Koerner (1990), menunjukkan bahwa umumnya kerusakan geosintesis, dalam hal ini adalah geotekstil terjadi pada saat pemasangan dan konstruksi. Penempatan agregat dan pelaksanaan pemadatan dengan alat berat mengakibatkan tegangan yang tinggi pada geotekstil [10]. Beberapa mode keruntuhan yang terjadi pada fondasi dangkal dengan beberapa lapis geotekstil seperti yang ditunjukan pada Gambar 7. Mode keruntuhan daya dukung pada tanah yang diperkuat geotekstil dapat dilihat pada Gambar 7.

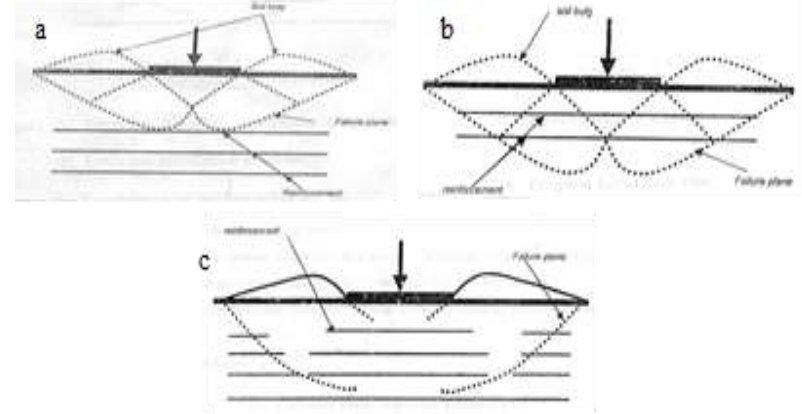

Gambar 7. Metode keruntuhan daya dukung tanah dengan perkuatan (a) Keruntuhan daya dukung terjadi di atas lapis perkuatan; (b) Keruntuhan pullout akibat deformasi; (c) Keruntuhan akibat putusnya perkuatan [10].

\section{Metode Penelitian}

\subsection{Sampel Tanah Berpasir}

Sampel tanah berpasirt untuk penelitian ini adalah tanah berpasir yang diambil disekitaran jalan Soekarno-Hatta tepatnya di lokasi lapangan tembak (Tugu Perdamaian) Palu, Sulawesi tengah. Lokasi ini dipilih karena pada lokasi ini merupakan daerah pengembangan kawasan khususnya untuk pembangunan perumahan dan kawasan wisata.

\subsection{Geotekstil}

Geosintetik yang digunakan pada penelitian adalah geotekstil UW-150 tipe woven dengan tebal $0,5 \mathrm{~mm}$, berat $150 \mathrm{gr} / \mathrm{m}^{2}$, dan kuat tarik $35 \mathrm{kN} / \mathrm{m}$.

\subsection{Pengumpulan Data}

Data diperoleh dari pengujian laboratorium meliputi uji sifat fisik dan mekanis tanah berpasir serta pengujian pemodelan tanah berpasir dengan perkuatan lembaran geotekstil yang bertujuan mengukur perubahan nilai daya dukung tanah pondasi dengan adanya perkuatan. Uji pemodelan dilakukan pada kondisi kepadatan tanah Dr $50 \%$, dengan variasi ukuran pondasi, B serta ukuran lebar perkuatan, Br. Tabel 1 adalah matriks variasi pemodelan untuk daya dukung.

Tabel 1. Matriks pemodelan daya dukung

\begin{tabular}{|c|c|c|c|}
\hline \multirow[b]{2}{*}{ Variasi } & \multicolumn{2}{|c|}{ Parameter Perkuatan } & \multirow[b]{2}{*}{ Keterangan } \\
\hline & $\begin{array}{c}\text { Lebar } \\
\text { Pondasi } \\
\text { (B) } \\
\end{array}$ & $\begin{array}{c}\text { Lebar } \\
\text { Perkuatan } \\
\text { (B) } \\
\end{array}$ & \\
\hline \multirow{3}{*}{$\begin{array}{c}\text { Tanpa } \\
\text { Perkuatan }\end{array}$} & $8 \mathrm{~cm}$ & & \multirow{12}{*}{$\begin{array}{c}\text { Kedalaman } \\
(\mathrm{u})=0.5 \mathrm{~B} . \\
\text { Jumlah } \\
\text { perkuatan } \\
(\mathrm{N})=3 \\
\text { Spasi }(\mathrm{z})= \\
0.25 \mathrm{~B}\end{array}$} \\
\hline & $10 \mathrm{~cm}$ & & \\
\hline & $12 \mathrm{~cm}$ & & \\
\hline 1 & $8 \mathrm{~cm}$ & $4 B$ & \\
\hline 2 & $8 \mathrm{~cm}$ & $5 B$ & \\
\hline 3 & $8 \mathrm{~cm}$ & $6 \mathrm{~B}$ & \\
\hline 4 & $10 \mathrm{~cm}$ & $4 B$ & \\
\hline 5 & $10 \mathrm{~cm}$ & $5 B$ & \\
\hline 6 & $10 \mathrm{~cm}$ & $6 \mathrm{~B}$ & \\
\hline 7 & $12 \mathrm{~cm}$ & 4B & \\
\hline 8 & $12 \mathrm{~cm}$ & $5 B$ & \\
\hline 9 & $12 \mathrm{~cm}$ & $6 \mathrm{~B}$ & \\
\hline
\end{tabular}


Gambar 8 adalah model uji daya dukung yang dilakukan di laboratorium dengan skala laboratorium

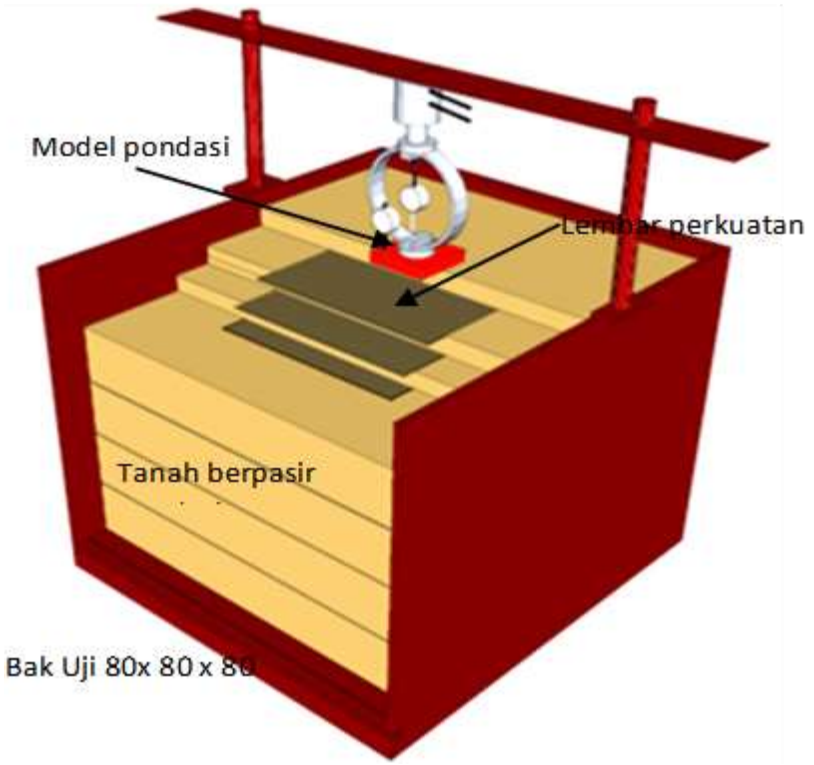

Gambar 8. Model uji daya dukung

Jumlah perkuatan, $\mathrm{N}$ yang dimodelkan 3 lembar, dengan jarak dari dasar pondasi, $\mathrm{u}=0.5 \mathrm{~B}$, jarak perkuatan $\mathrm{z}=$ $0.25 \mathrm{~B}$ dan lebar perkuatan, $\mathrm{Br}=4 \mathrm{~B}, \mathrm{Br}=5 \mathrm{~B}$ dan $\mathrm{Br}=6 \mathrm{~B}$. $\mathrm{B}$ adalah lebar ponds bujursangkar.

\subsection{Analisis Data Data}

Hasil uji daya dukung akan disajikan dalam bentuk tabel dan grafik. Grafik yang akan ditampilkan yaitu grafik hubungan daya dukung, (qu) dan penurunan. Penentuan nilai daya dukung ultimit dilakukan dengan pendekatan Tangent Intersection Method [14]. Setelah itu dilakukan analisis dimensionless, untuk menghasilkan nilai Bearing Capacity Ratio (BCR), yang merupakan rasio antara daya dukung ultimit tanah fondasi yang diperkuat dengan daya dukung ultimit tanah fondasi yang tidak diperkuat.

\section{Hasil dan Pembahasan}

\subsection{Sifat Fisik Tanah}

Sifat fisik dan mekanis tanah berpasir dapat dilihat pada Tabel 2.

Tabel 2. Sifat fisik dan mekanis tanah berpasir

\begin{tabular}{lll}
\hline Parameter & Satuan & Nilai \\
\hline Klasifikasi tanah & - & $\mathrm{SP}$ \\
\hline Berat jenis, Gs & $\mathrm{kg} / \mathrm{cm}^{3}$ & 2.67 \\
\hline $\begin{array}{l}\text { Berat isi kering } \\
\text { minimum, } \gamma \mathrm{d} \text { min }\end{array}$ & $\mathrm{gr} / \mathrm{cm}^{3}$ & 1.57 \\
\hline $\begin{array}{l}\text { Berat isi kering } \\
\text { minimum, } \gamma \mathrm{d} \text { min }\end{array}$ & $\mathrm{gr} / \mathrm{cm}^{3}$ & 1.67 \\
\hline $\begin{array}{l}\text { Berat isi pada Dr 50\%, } \\
\gamma \mathrm{d}\end{array}$ & $\mathrm{gr} / \mathrm{cm}^{3}$ & 1.62 \\
\hline Sudut Gesek, $(\mathrm{Dr} 50 \%)$ & $\circ$ & 29.4 \\
\hline Kohesi (Dr 50\%) & $\mathrm{kg} / \mathrm{cm}^{2}$ & 0.057 \\
\hline
\end{tabular}

\subsection{Pemodelan Daya Dukung}

1) Daya Dukung Terhadap Variasi Lebar Perkuatan

Hasil yang diperoleh dari pengujian daya dukung adalah hubungan nilai penurunan dengan beban yang bekerja. Gambar 9 memperlihatkan hubungan nilai penurunan dan beban yang bekerja pada beberapa variasi ukuran pondasi serta lebar perkuatan Br. Dari grafik hubungan ini kemudian ditentukan nilai daya dukung batas dengan menggunakan metode tangent intersection. Nilai daya dukung batas dari Gambar 10 terlihat akan semakin tinggi nilainya jika ukuran pondasi semakin besar. Pada Tabel 3 memperlihatkan nilai daya dukung batas yang diperoleh dari hasil pengujian pemodelan dan perhitungan teoritis menggunakan teori Terzaghi. Nilai daya dukung menggunakan perhitungan secara teoritis dan pengujian daya dukung pemodelan nilai yang diperoleh tidak terlalu mendekati. Disebabkan karena kondisi tanah di dalam bak pengujian kepadatannya kemungkinan tidak homogen dari pada kondisi kepadatan pada uji geser langsung pada Dr $50 \%$, hal ini karena proses pembentukan tanah dalam bak lebih susah dibandingkan pada cincin uji geser langsung.

Tabel 3. Nilai daya dukung batas secara teoritis dan hasil uji pemodelan

\begin{tabular}{ccc}
\hline Lebar fondasi (B) & $\begin{array}{c}\text { qu (model) } \\
\mathbf{k N} / \mathbf{m}^{\mathbf{2}}\end{array}$ & $\begin{array}{c}\text { qu (teoritis) } \\
\mathbf{k N} / \mathbf{m}^{\mathbf{2}}\end{array}$ \\
\hline $8 \mathrm{~cm} \times 8 \mathrm{~cm}$ & 34 & 60,752 \\
\hline $10 \mathrm{~cm} \times 10 \mathrm{~cm}$ & 62 & 60,916 \\
\hline $12 \mathrm{~m} \times 12 \mathrm{~cm}$ & 80 & 61,100 \\
\hline
\end{tabular}

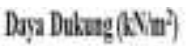

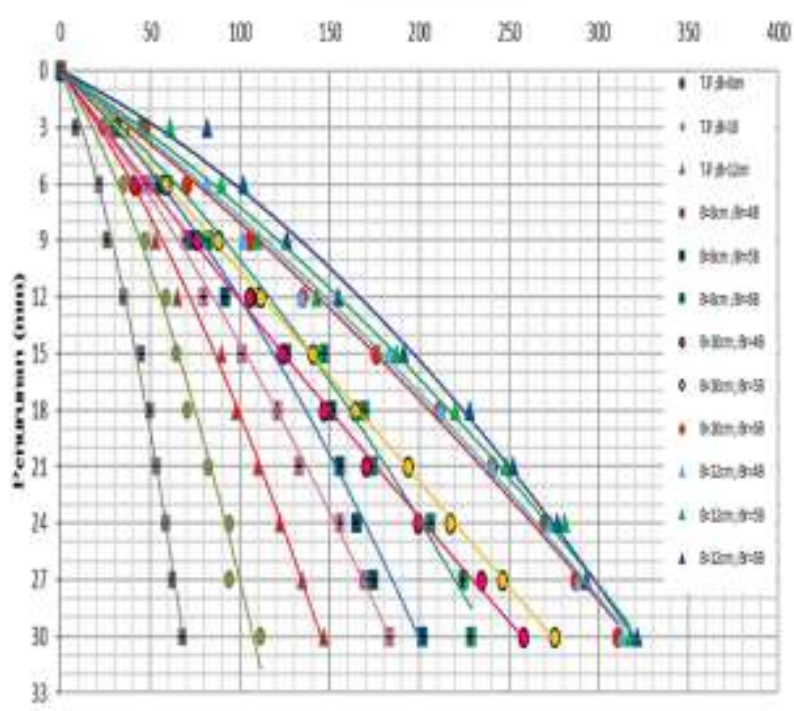

Gambar 9. Grafik hubungan penurunan dan daya dukung pada variasi lebar perkuatan dan ukuran pondasi.

Tabel 4 memperlihatkan persentase peningkatan daya dukung pada variasi lebar fondasi (B) terhadap nilai daya dukung tanpa perkuatan, selisih peningkatan daya dukung antara persentase daya dukung variasi lebar 
REKOnSTRUKSI TADULAKO: Civil Engineering Journal on Research and Development, Vol. 2(2), September 2021

fondasi yang berbeda- beda, serta penurunan yang terjadi.

Tabel 4. Nilai daya dukung ultimit, qu dan \% peningkatan terhadap variasi lebar perkuatan, $\mathrm{Br}$

\begin{tabular}{ccccc}
\hline \multirow{2}{*}{$\begin{array}{c}\text { Lebar } \\
\text { perkuatan }\end{array}$} & Variasi pondasi & $\begin{array}{c}\text { Qu } \\
\text { KN/m2 }\end{array}$ & $\begin{array}{c}\text { \% } \\
\text { peningkatan }\end{array}$ & $\begin{array}{c}\mathbf{S} \\
\mathbf{m m}\end{array}$ \\
\hline $4 \mathrm{~B}$ & $8 \times 8 \mathrm{~cm}^{2}$ & 70 & & 8 \\
\cline { 2 - 5 } & $10 \times 10 \mathrm{~cm}^{2}$ & 100 & 14.6 & 12 \\
\cline { 2 - 5 } & $12 \times 12 \mathrm{~cm}^{2}$ & 135 & 1.5 & 9.6 \\
\hline $5 \mathrm{~B}$ & $8 \times 8 \mathrm{~cm}^{2}$ & 86 & & 9 \\
\cline { 2 - 5 } & $10 \times 10 \mathrm{~cm}^{2}$ & 110 & -15.5 & 10.5 \\
\hline $6 \mathrm{~B}$ & $12 \times 12 \mathrm{~cm}^{2}$ & 140 & -2.4 & 9 \\
& $8 \times 8 \mathrm{~cm}^{2}$ & 90 & & 7.5 \\
\cline { 2 - 5 } & $10 \times 10 \mathrm{~cm}^{2}$ & 100 & -55 & 9 \\
\hline & $12 \times 12 \mathrm{~cm}^{2}$ & 135 & -15.9 & 8.5 \\
\hline
\end{tabular}

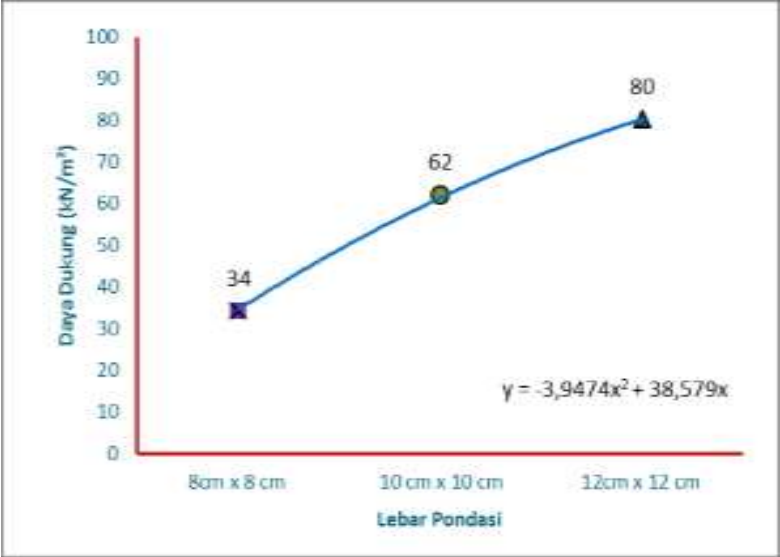

Gambar 10. Grafik hubungan nilai daya dukung pondasi dengan lebar berbeda tanpa perkuatan

Tabel 4 memperlihatkan persentase peningkatan daya dukung pada variasi lebar perkuatan 4B berkisar antara $61,3 \%$ sampai $105,9 \%$ dan persentase terbesar diperoleh pada pemodelan dengan lebar pondasi (B) $8 \mathrm{~cm} \times 8 \mathrm{~cm}$ dengan nilai $105,9 \%$. Selisih peningkatan daya dukung terbesar pada lebar pondasi (B) (B) $8 \mathrm{~cm} \times 8 \mathrm{~cm}$ dan $10 \mathrm{~cm} \times 10 \mathrm{~cm}$ sebesar $44,6 \%$ menandakan peningkatan yang cukup besar pada lebar pondasi (B) $8 \mathrm{~cm} \times 8 \mathrm{~cm}$. Dan pada lebar pondasi $10 \mathrm{~cm} \times 10 \mathrm{~cm}$ presentasi peningkatan daya dukungnya paling rendah dibandingkan variasi lebar pondasi (B) lainnya, sehingga pada lebar pondasi (B) $10 \mathrm{~cm}$ x $10 \mathrm{~cm}$ kurang efektif menggunakan lebar perkuatan $(\mathrm{Br})$ 4B karena persentase peningkatan daya dukung dari tanpa perkuatan terhadap dengan menggunakan perkuatan masih rendah.

Untuk variasi lebar perkuatan 5B persentase p eningkatan daya dukung yang diperoleh pada pemodelan juga mengalami peningkatan yaitu sebesar $75 \%$ sampai $152,9 \%$ dan persentase peningkatan daya dukung terbesar berada pada lebar pondasi (B) $8 \mathrm{~cm} \times 8$ $\mathrm{cm}$ dengan nilai persentase sebesar $152,9 \%$. Selisih peningkatan daya dukung sebesar $75,5 \%$ pada lebar pondasi (B) $8 \mathrm{~cm} \times 8 \mathrm{~cm}$ dan $10 \mathrm{~cm} \times 10 \mathrm{~cm}$ dan merupakan selisih peningkatan terbesar pada variasi lebar pondasi (B). Persentase peningkatan daya dukung pada variasi ini lebih besar dari variasi sebelumnya sehingga penambahan lebar perkuatan untuk setiap masing-masing lebar pondasi (B) sangat berpengaruh.

Pada variasi 6B persentase peningkatan daya dukung yang diperoleh yaitu antara 93,8 \% sampai 164,7\% dan persentase peningkatan daya dukung terbesar diperoleh pada lebar pondasi (B) $8 \mathrm{~cm}$ x $8 \mathrm{~cm}$. Sedangkan selisih peningkatan daya dukung terbesar pada variasi ini mencapai $55 \%$ pada lebar pondasi $8 \mathrm{~cm} \times 8 \mathrm{~cm}$ dan $10 \mathrm{~cm}$ x $10 \mathrm{~cm}$ lebih kecil dibandingkan selisih peningkatan daya dukung pada variasi sebelumnya.

Perubahan lebar perkuatan (Br) 4B, 5B dan 6B menunjukan adanya peningkatan daya dukung dengan penurunan yang semakin kecil. Selain itu persentase peningkatan daya dukung yang terus meningkat dari masing-masing lebar perkuatan $(\mathrm{Br})$ pada setiap lebar pondasi (B), sehingga lebar perkuatan sangat berpengaruh dalam meningkatkan daya dukung. Dapat disimpulkan bahwa penggunaan geotekstil dapat meningkatkan daya dukung dan dapat memperkecil penurunan yang terjadi.

Nilai $B C R$ mengalami penurunan seiring bertambahnya lebar pondasi yang dimodelkann. Pada Tabel 5 dapat dilihat bahwa pada lebar perkuatan $5 \mathrm{~B}$ dan $6 \mathrm{~B}$ untuk lebar fondasi (B) $8 \mathrm{~cm} \times 8 \mathrm{~cm}$ dan $10 \mathrm{~cm} \mathrm{x} 10 \mathrm{~cm}$ memberikan kontribusi yang besar dalam peningkatan nilai BCR. Pada lebar perkuatan 4B juga memberikan pengaruh dalam meningkatkan daya dukung hanya saja tidak terlalu besar. Pada lebar pondasi (B) $12 \mathrm{~cm} \mathrm{x} 12$ $\mathrm{cm}$ yang paling rendah nilai $B C R$ nya hal ini dikarenakan ukuran lebar perkuatan 4B tidak mampu memikul beban dengan lebar pondasi (B) $12 \mathrm{~cm} \mathrm{x} 12 \mathrm{~cm}$. Dapat dilihat nilai BCR terbesar diperoleh pada lebar ppndasi (B) $8 \mathrm{~cm}$ $\mathrm{x} 8 \mathrm{~cm}$.

2) Analisis Bearing Capaity Ratio, $B C R$

Tabel 5 menunjukkan nilai rasio daya dukung (BCR) yang diperoleh berbagai variasi pemodelan perkuatan geotekstil. Nilai rasio daya dukung diperoleh dari penambahan lebar perkuatan dibawah pondasi, dimana 
semakin lebar perkuatan yang diberikan maka nilai BCR semakin meningkat. Peningkatan nilai $B C R$ paling besar pada lebar pondasi (B) $8 \mathrm{~cm} \times 8 \mathrm{~cm}$ untuk lebar perkuatan 4B, 5B dan 6B.

Tabel 5. Variasi nilai daya dukung dan CBR

\begin{tabular}{|c|c|c|c|c|}
\hline Variasi & \multicolumn{2}{|c|}{$\begin{array}{c}\text { Variasi } \\
\text { Pemodelan }\end{array}$} & $\begin{array}{c}\text { Daya } \\
\text { Dukung, } \\
\text { qu } \\
\left(\mathbf{k N} / \mathbf{m}^{2}\right)\end{array}$ & BCR \\
\hline \multirow{3}{*}{$\begin{array}{l}\text { Tanpa } \\
\text { perkuatan }\end{array}$} & \multicolumn{2}{|c|}{$8 \mathrm{~cm} \times 8 \mathrm{~cm}$} & 34 & 1,00 \\
\hline & \multicolumn{2}{|c|}{$10 \mathrm{~cm} \times 10 \mathrm{~cm}$} & 62 & 1,00 \\
\hline & \multicolumn{2}{|c|}{$12 \mathrm{~cm} \times 12 \mathrm{~cm}$} & 80 & 1,00 \\
\hline \multirow{9}{*}{$\begin{array}{l}\text { Variasi } \\
\text { lebar } \\
\text { perkuatan } \\
\text { dan lebar } \\
\text { pondasi }\end{array}$} & \multirow{3}{*}{$\begin{array}{l}\text { Pondasi } \\
8 \mathrm{~cm} \mathrm{x} 8 \\
\mathrm{~cm}\end{array}$} & $4 \mathrm{~B}$ & 70 & 2,06 \\
\hline & & $5 B$ & 86 & 2,53 \\
\hline & & $6 \mathrm{~B}$ & 90 & 2,65 \\
\hline & \multirow{3}{*}{$\begin{array}{l}\text { Pondasi } \\
10 \mathrm{~cm} \mathrm{x} \\
10 \mathrm{~cm}\end{array}$} & $4 \mathrm{~B}$ & 100 & 1,61 \\
\hline & & $5 B$ & 110 & 1,77 \\
\hline & & $6 \mathrm{~B}$ & 130 & 2,10 \\
\hline & \multirow{3}{*}{$\begin{array}{l}\text { Pondasi } \\
12 \mathrm{~cm} \mathrm{x} \\
12 \mathrm{~cm}\end{array}$} & $4 \mathrm{~B}$ & 135 & 1,69 \\
\hline & & $5 B$ & 140 & 1,75 \\
\hline & & $6 \mathrm{~B}$ & 155 & 1,94 \\
\hline
\end{tabular}

Nilai $B C R$ mengalami penurunan seiring dari bertambahnya lebar fondasi yang diberikan. Pada grafik tersebut dapat dilihat bahwa pada lebar perkuatan 5B dan 6B untuk lebar fondasi (B) $8 \mathrm{~cm} \mathrm{x}$ $8 \mathrm{~cm}$ dan $10 \mathrm{~cm}$ x $10 \mathrm{~cm}$ memberikan kontribusi yang besar dalam peningkatan nilai BCR. Pada lebar perkuatan 4B juga memberikan pengaruh dalam meningkatkan daya dukung hanya saja tidak terlalu besar. Pada lebar fondasi (B) $12 \mathrm{~cm} \mathrm{x} 12 \mathrm{~cm}$ yang paling rendah nilai $B C R$ nya hal ini dikarenakan ukuran lebar perkuatan 4B tidak mampu memikul beban dengan lebar fondasi (B) $12 \mathrm{~cm} \times 12 \mathrm{~cm}$. Dapat dilihat nilai BCR terbesar diperoleh pada lebar fondasi (B) $8 \mathrm{~cm} \times 8 \mathrm{~cm}$.

Das (2011), menyatakan bahwa pada pondasi dangkal beban ultimit tercapai pada saat penurunan fondasi 4 $10 \%$ dari lebar pondasi (B) [15]. Hal ini dibenarkan bila keruntuhan yang terjadi keruntuhan geser umum, tetapi dalam kasus keruntuhan geser pons dan keruntuhan geser lokal, beban ultimit tercapai pada saat penurunan sebesar $15-25 \%$ dari lebar pondasi (B).

Tabel 6. Perbandingan $q u$ dengan 3 metode

\begin{tabular}{lccc}
\hline $\begin{array}{c}\text { Lebar } \\
\text { Pondasi (B) }\end{array}$ & $\begin{array}{c}\boldsymbol{q}_{\boldsymbol{u}} \text { (tangent) } \\
\mathbf{k N} / \mathbf{m}^{\mathbf{2}}\end{array}$ & $\begin{array}{c}\boldsymbol{q}_{\boldsymbol{u}} \\
(\text { teoritis) } \\
\mathbf{k N} / \mathbf{m}^{\mathbf{2}}\end{array}$ & $\begin{array}{c}\boldsymbol{q}_{\boldsymbol{u}} \\
(\mathbf{v e s i c}) \\
\mathbf{k N} / \mathbf{m}^{\mathbf{2}}\end{array}$ \\
\hline $8 \mathrm{~cm} \times 8 \mathrm{~cm}$ & 34 & 60,752 & 44 \\
\hline $10 \mathrm{~cm} \times 0 \mathrm{~cm}$ & 62 & 69,919 & 81 \\
\hline $12 \mathrm{~cm} \mathrm{\times} \mathrm{12} \mathrm{cm}$ & 80 & 61,100 & 123 \\
\hline
\end{tabular}

\section{Kesimpulan}

Nilai daya dukung batas, qu pada kondisi tanpa perkuatan untuk $\mathrm{B}=8 \mathrm{~cm} \times 8 \mathrm{~cm}$ sebesar $34 \mathrm{kN} / \mathrm{m}^{2}, \mathrm{~B}=$ $10 \mathrm{~cm} \times 10 \mathrm{~cm}=62 \mathrm{kN} / \mathrm{m}^{2}$ dan $\mathrm{B}=12 \mathrm{~cm} \mathrm{x} 12 \mathrm{~cm}$ sebesar $80 \mathrm{kN} / \mathrm{m}^{2}$. Pada pengujian daya dukung menggunakan perkuatan geotekstil dengan variasi lebar perkuatan $(\mathrm{Br})$
4B, 5B dan 6B diperoleh daya dukung batas yaitu $\mathrm{B}=8 \mathrm{~cm}$ x $8 \mathrm{~cm}$ sebesar $70 \mathrm{kN} / \mathrm{m}^{2}$ sampai $90 \mathrm{kN} / \mathrm{m}^{2}, \mathrm{~B}=10 \mathrm{~cm} \mathrm{x}$ $10 \mathrm{~cm}$ sebesar $100 \mathrm{kN} / \mathrm{m}^{2}$ sampai $130 \mathrm{kN} / \mathrm{m}^{2}$ dan $\mathrm{B}=$ $12 \mathrm{~cm}$ x $12 \mathrm{~cm}$ sebesar $135 \mathrm{kN} / \mathrm{m}^{2}$ sampai $155 \mathrm{kN} / \mathrm{m} \mathrm{m}^{2}$. Dari pengujian pemodelan daya dukung tanah dengan menggunakan variasi lebar fondasi (B) dan lebar perkuatan (Br) diperoleh lebar perkuatan yang efektif untuk lebar fondasi $8 \mathrm{~cm} \times 8 \mathrm{~cm}$ adalah $4 \mathrm{~B}, 5 \mathrm{~B}$ dan $6 \mathrm{~B}$. Untuk lebar fondasi $10 \mathrm{~cm} \mathrm{x} 10 \mathrm{~cm}$ dan $12 \mathrm{~cm} \mathrm{x} 12 \mathrm{~cm}$ belum di dapatkan lebar perkuatan yang efektif karena daya dukung terus mengalami peningkatan dan belum mencapai puncak. Untuk ukuran pondasi $10 \mathrm{~cm} \times 10 \mathrm{~cm}$ dan $12 \mathrm{~cm} \times 12 \mathrm{~cm}$, membutuhan ukuran lebar perkuatan yang lebih besar dari $6 \mathrm{~B}$.

Nilai daya dukung tanah yang diperoleh dengan menggunakan rumus Terzaghi lebih seragam dibandingkan pemodelan di bak uji, hal ini disebabkan kesulitan membentuk kepadatan pada bak uji dibandingkan pemodelan pada cincin. Untuk daya dukung batas yang diperoleh dengan menggunakan Teori Vesic lebih besar dari pada menggunakan pendekatan Tangen Intersection Method, hal ini disebabkan karena Teori Vesic berasumsi pada keruntuhan geser lokal dan keruntuhan geser pons, sedangkan untuk metode Tangen Intersection Method berasumsi pada keruntuhan geser umum berdasarkan penurunan yang terjadi.

\section{Daftar Pustaka}

[1] Y. Zaika and B.A. Kombino, "Penggunaan Geotextil Sebagai Alternatif Perbaikan Tanah Terhadap Penurunan Pondasi Dangkal”, Jurnal Rekayasa Sipil. vol. 4, no. 2, p. 91, 2010.

[2] S.A. Nugroho, "Studi Daya Dukung Pondasi Dangkal pada Tanah Gambut dengan Kombinasi Geotekstil dan Grid Bambu”, Jurnal Teoretis dan Terapan Bidang Rekayasa Sipil, vol. 18, no. 1, p. 31, 2011.

[3] P. Utomo, "Daya Dukung Ultimit Pondasi Dangkal di Atas Tanah Pasir yang Diperkuat Geogrid", Civil Engineering Dimension, vol. 6, no. 1, p. 15, 2004.

[4] Y.D.J. Prasasti, A. Munawir, and Suroso, "Pengaruh Variasi Panjang Lapisan Dan Jarak Vertikal Antar Geotekstil Terhadap Daya Dukung Pondasi Menerus Pada Pemodelan Lereng Pasir Kepadatan 74\%", Jurnal Mahasiswa Jurusan Teknik Sipil, vol. 1, no. $1,2014$.

[5] Martini and F. Al-Anshori, "Kajian Pengaruh Jumlah Dan Lebar Perkuatan Geotekstil Terhadap Daya Dukung Tanah Gambut", Infrastruktur, vol. 4, no. 2, p. 95, 2014.

[6] B.K. Thirayo, "Pengaruh Ukuran dan Kedalaman Geotekstil Teranyam Tipe HRX 200 terhadap Daya Dukung Ultimit dan Penurunan Tanah Lempung Lunak", Semesta Teknika, vol. 16, no. 1, p. 91, 2013.

[7] A. Munawir, W. Suyadi, and H. Saraswati, "Pengaruh Pembebanan Eksentris pada Pondasi Persegi Panjang Terhadap Daya Dukung dan Penurunan Tanah Pasir 
dengan Perkuatan Geotekstil”, Rekayasa Sipil, vol. 3, no. 2, p. 101, 2009.

[8] P. Yulianti, "Studi Pemodelan Perkuatan Pondasi Dangkal Pada Tanah Lempung Lunak Menggunakan Kombinasi Geotekstil Woven dan Grid Bambu Dengan Bantuan Program Plaxis", Jurnal Teknik Sipil dan Lingkungan, vol. 2, no. 3, p. 320, 2014.

[9] H.C. Hardiyatmo, Teknik Pondasi 1, Jakarta: PT. Gramedia Pustaka Utama, 1996.

[10] R.M. Koerner, Designing with Geosynthetics (Second Edition), New Jersey: Englewood Cliff, 1990.

[11] A. Widianti, "Pengaruh Jumlah Lapisan dan Spasi Perkuatan Geosintetik terhadap Kuat Dukung dan Penurunan Tanah Lempung Lunak", Semesta Teknika, vol. 15, no. 1, p. 91, 2012.
[12] R. Riyadi, M. Yusa, and S.A. Nugroho, "Studi Daya Dukung Pondasi Dangkal Dengan Kombinasi Perkuatan Geotekstil dan Susunan Bambu", Dinamika Teknik Sipil, vol. 11, no. 1, p. 30, 2011.

[13] I.G.N.N. Wismantara and P. Budiarnaya, "Metode Peningkatan Daya Dukung Tanah Lunak", Jurnal Ilmiah Telsinas, vol. 3, no. 2, p. 37, 2020.

[14] N.S. Surjandari, B. Setiawan, and J.I.S. Gea, "Analisis Kapasitas Dukung Dan Penurunan Pondasi Konstruksi Sarang Laba-Laba Dengan Perkuatan Geotextile Woven Pada Tanah Lunak", Matriks Teknik Sipil, vol. 8, no. 2, p. 555, 2017.

[15] B.M. Das, Principles of Geotechnical Engineering (Seventh Edition), Stamford: Cengage Learning, 2010. 
This page is intentionally left blank 